\title{
Poverty of Older Women in Slovenia
}

\author{
VESNA LESKOŠEK * \\ Faculty of Social Work \\ University of Ljubljana \\ Ljubljana, Slovenia
}

\author{
Review paper \\ UDK: 364.2-055.2-053.9(497.4) \\ doi: $10.3935 /$ rsp.v26i2.1586 \\ Received: August 2018
}

This article aims to problematize a socially relevant, but politically overlooked issue of poverty among older women. Data show that poverty among women is a challenge for most EU countries and wider. However, it cannot be explained without understanding gender-specific life courses of women. We present the differences between older women and men in terms of the risk of poverty and compare them with those in EU countries. The article is based on secondary data, i.e. the Survey on Income and Living Conditions (EU SILC), which enable comparisons among EU countries. We have established that the gender gap in terms of risk of poverty widens in old age. The at-risk-of-poverty rate for women is much higher in Slovenia than in other EU states. The gap is especially large in the age group 75 and over. Slovenia has not been successful in coping with the risk of poverty problem, because it failed to introduce special measures to reduce the general risk of poverty and gender gap. work.

Key words: poverty, life course, gender pension gap, employment, care

\section{INTRODUCTION}

The aim of this article is to draw attention to the pressing yet politically overlooked issue of poverty among older women. Gender difference in poverty in old age is high in most countries in the European Union and beyond. Poverty of older women is two to three times higher than the poverty of men, what will be presented latter in the article. Literature review and comparative research data show that social security systems around the world insufficiently address the problem neglecting the core issue of gender inequalities over the life-course (Barrientos et al., 2003; Bettio et al., 2013; Börcsh Supan et al., 2011; Burkevica et al., 2015; Gianni et al., 2015). Review also shows that poverty in old age cannot be understood by studying merely statistical data over a certain period of time, since it is a result of the accumulation of inequalities throughout one's life course. Furthermore, poverty among older women cannot be fully understood without taking into account the socialization of women into expected social and gender roles which affect their life courses. Even though the causes of poverty of women in old age are known, the problem of political recognition remains what impacts the survival of women in old age. Poverty reduces their life to taking care just of basic needs, such as having something to eat and enough money to pay the bills what in most cases is already a struggle. The problem affects also elderly women in Slovenia.

\footnotetext{
* Vesna Leskošek, Faculty of Social Work / Fakulteta za socialno delo, University of Ljubljana / Univerza v Ljubljani, Topniška ulica 31, 1000 Ljubljana, Slovenia / Ljubljana, Slovenija, vesna.leskosek@fsd.uni-lj.si
} 
Data for Slovenia show that the risk of poverty is higher for women than for men in all age groups ${ }^{1}$, and after the age of 60 the gender gap becomes even wider what is also a consequence of the pension system and women's work histories, i.e. their inclusion in paid work. In 2016, slightly more than 370,000 women in Slovenia were employed (45 percent of the entire active working population). More women than men have tertiary education (59 percent of women). More women than men work part-time. In 2017 the share of men on part-time contacts was 36.6 percent and the share of women was 63.4 percent (SORS, Labour market statistics). The percentage of children enrolled in the kindergarten is growing (80.4 percent in 2017/18, compared with 2004 when it was just 61.4), but still 20 percent of children stay at home and are either in care with grandparents or at home (SORS, Pre-school indicators). More women than men age $65+$ live in bad housing conditions but here the difference is not substantial. In 201623.5 percent of men and 24.8 percent of women lived in bad dwellings (SORS, Housing deprivation). The average gross monthly earnings of women with college or university education amounted to EUR 2,146, which is EUR 450 less than the average gross salary earned by men with the same education level (SORS, International Women's Day, 2018). In 2016, the at-riskof-poverty rate for women was 15.2 percent, compared to 12.5 percent for men. Data on material deprivation show that 10.9 percent of men and 16.7 percent of women live in households that cannot afford three of the nine items due to the lack of financial resources. Severe deprivation (four of nine items) experienced 3.9 percent of men and 6.4 percent of women. Although Slovenia scores high in the gender equality index (EIGE, 2015) - it is ranked $10^{\text {th }}$ among the
EU countries - in terms of poverty among older women it is near the bottom of the list of EU states.

In the article, we first present comparative data to provide a wider EU context for our analysis. In addition to data on poverty, we will also take into account data on pensions which in most cases are the only stable source of income in old age. Our analysis is based on existing data on poverty and pensions. Data on poverty are derived from the statistical data of the European Union Survey on Income and Living Conditions (EU SILC), which is carried out in all EU countries and wider (Island, Norway, Switzerland, Serbia, Macedonia). The basis for the sample used in this study is the Central Population Register, with additional data obtained from the Property Register and Household Register. The survey is conducted by phone and is taking place annually, from mid-January to the end of March (SORS, Explanation of methodology, 2016). In addition, we used the data of the Statistical Office of the Republic of Slovenia (hereafter SORS) and Eurostat. We will conclude with listing most important facts and life situations of women over life-course that influence their financial situation in old age. We will emphasise the role of the welfare state in recognising women's contribution to overall well-being and prosperity of the state and thus providing them with social security and decent ageing regardless to their labour market participation.

\section{AN OVERVIEW OF STUDIES ON THE POVERTY AMONG OLDER WOMEN}

A review of the Slovenian research studies shows that poverty among older women is not high on the research agenda. This could be attributed to the historical margin-

${ }^{1}$ In 2016, Slovenia ranked 41st among 189 countries with respect to the GDP per capita. Source: Global Finance: https://www.gfmag.com/global-data/economic-data/richest-countries-in-the-world?page=12 
alization of women issues, including poverty. International comparisons show that in rich countries approximately one fifth of older women age 75+ live in poverty (Gornick et al., 2009a). The most precarious situation is that of older women who live alone or support dependent family members. The data collected in the Luxembourg Wealth Study (LWS, Slovenia was included in the ninth research cycle), revealed significant differences in poverty if the percentage of property ownership and wealth is taken into account. Compared to the USA, where older women have low incomes but own properties, women in Sweden, Finland, Germany, Italy and Great Britain have better incomes but also own a rather small percentage of properties (except in Sweden) (Gornick et al., 2009a). However, among those women that own a property most of them are owners of houses in which they live, that is to say, the kind of property that does not generate income which could be used to reduce poverty. The comparative OECD data show that women retire earlier than men and live longer, so their income and property must be sufficient to support them through a longer period of time (Gornick et al., 2009b). In the group of countries included in LWS study, women in Sweden retire later than their counterparts elsewhere half of the women in the age group 60-64 still work. In Italy, the share of working women in this age group is much lower -7 percent. In Great Britain and Germany it is approximately 25 percent, and in the USA 42 percent (Gornick et al., 2009b). The low percentage for Italy is also related to women's lower participation in the labour force.

Barrientos et al. (2003) believe that income poverty among older women in the EU will increase even more. Globalization-related demands for structural reforms and institutional adjustments, changes on the labour market and in employment regimes, and social reforms in particular, affect older people, especially women, since their working lives are much more unpredictable and precarious than those of men. Although poverty in old age is well documented problem, the issue is more or less overlooked because older people do not actively participate in society and are therefore less visible (Barrientos et al., 2003).

The reduction of poverty in old age significantly depends on the accessibility of cash allowances and various services and programmes, the availability of decent housing and the maintenance of social or support networks (Barrientos et al., 2003). Governmental responses to this problem have mainly been inadequate, but there are several examples of good practices. Canada managed to reduce poverty level among older women by introducing the Guaranteed Income Supplement (Gornick et al., 2009a). A similar effect was achieved in Slovenia through the minimum pension supplement, where the eligibility criteria were different than those used in granting cash allowances. With the 2012 amendments of the law regulating social assistance benefits in cash, the income supplement became a social assistance benefit which is subject to the same criteria as any other cash allowance (more on this later in the text).

Data of the European Commission (Gianni et al., 2015; Bettio et al., 2013) and the European Institute for Gender Equality (Burkevica et al., 2015) show that in all 28 EU states women's pensions are lower than men's pensions. The difference between the average gross pensions of women and men in the age group 65 or over is 38 percent, which is more than twice as large as the gender pay gap. In more than half of the EU countries (seventeen of them altogether), the gender gap in pension ${ }^{2}$ (GGP)

\footnotetext{
${ }^{2}$ We are using two similar abrevations, the first is gender gap in pensions (GGP) and the second is gender pay gap (GPG).
} 
in the age group 65-69 is higher than that in the age group 75 and over, meaning that the education level and greater participation in the labour force do not reduce the gap.

The complexity of this phenomenon - the high GGP in rich welfare-states with strong gender equality policies, and a higher gap for younger, more educated and emancipated women - is also related to the fact that social policies differ over time and across countries, intertwining with the life courses of women who migrate and change jobs, statuses and professions. As we mentioned earlier in the text, the outcomes and consequences of women's and men's life courses differ greatly due to gendered social roles. Dewilde et. al (2011: 103) studied the long-term impact of divorce and separation in thirteen EU states. The results show that women more often experience financial shortfalls, more often apply for social allowances and more often have problems with obtaining suitable dwelling. These issues can be resolved through social policy measures as well as the labour market regulation. The economic consequences are less severe for women who live in the countries that provide higher cash supplements for single-parent families and ensure access to services such as child care. The policies aimed at reconciling family life and work, which primarily focus on the improvement of employment opportunities for women, have been unequivocally proven to be effective. Policies that enable women to enter the labour market (including measures targeted at alleviating precarious situations such as motherhood, sick leaves, or care responsibilities which may lead women to opt out of employment), have a positive effect on the level of their pensions among other things (Lyberaki et al., 2011; Lewis, 2009).

Data show that despite (or because of) measures of social and other related policies, inequalities build up in high old age.
The findings of the study about the interaction of social policy and life courses conducted by Börcsh-Supan et al. (2011) support this thesis. Certain measures have direct impacts. For example, eligibility requirements for retirement or disability pension and specific features of the labour market have direct impacts on early retirement. On the other hand, long-term measures concerning education, healthcare and housing have indirect and mutually related impacts (Börcsh-Supan et al. 2011: 4). The increase in poverty points to the need to introduce a form of minimal income in old age that would not be tied to the working history of the individual (Goedemé, 2012).

These facts remind us that what at first glance appears to be a woman's individual choice, for example, a decision to take on care work in the family, or opt out of paid employment or accept a precarious job, is in fact a result of social and cultural expectations that operate on the structural level through institutions, the labour market, education system, consumption, legislation and the like (Baxter et al., 2008).

\section{THE EXTENT OF POVERTY AMONG WOMEN IN SLOVENIA}

During the early 1990s, poverty was addressed by only few scholars in Slovenia (Stanovnik, 1992; Novak, 1992), and the situation has not much changed over time. Consequently, information on poverty in Slovenia can be derived only from EU SILC data and international studies.

One in four women in Slovenia born before 1945 had been in paid employment for less than 14 years altogether. In most Eastern European countries, women did not experience such long interruptions in their careers (Tinios et al., 2015: 48). The same holds true of the pension gap - in most Eastern European countries the GGP is less than 16 percent. This data is inter- 
esting because it challenges the prevailing assumption about women's inclusion in the labour market during the socialist era. As Kanjuo Mrčela and Cernigoj Sadar (2011) established, ever since the mid-1970s support for the reconciliation of work and family life in Slovenia has been growing, but the mere existence of political measures does not necessarily mean that various options are readily accessible in practice, with the problem being of structural rather than individual nature. The data also indicate that this issue is closely connected with the private sphere, that is, the gender division of (care) work and power relations within families.

According to the Eurostat data, in 2010 Slovenia had the highest increase in poverty in the EU - 1.4 percent compared to the previous year. Furthermore, in 2009 only 3 countries had a lower at-risk-of-poverty rate than Slovenia, but in 2015 there were 7 such countries. Reasons for the increase in poverty are complex and cannot be blamed on the economic crisis alone. The response of the government to the crisis plays an equally important role, so countries which set aside larger funds for social security were more successful in resolving the poverty issue than those which reduced funds. Slovenia belongs in the latter group - according to
OECD data, it decreased the percentage of the GDP earmarked for family and social allowances (OECD, 2017).

Data in Table 1 show slight differences between genders in various age groups in terms of poverty during their active life, with the poverty risk rate being slightly higher for women. The situation of women during their active years is not determined by their income only, but also by the economic situation of the household. This is best illustrated with data on the working poor, where poverty among men is characteristically higher than poverty among women. The reason is not that women receive higher salaries, but the fact that more employed men are the sole wage earners in the household (Leskošek et al., 2013). Greater differences between genders begin to show during later stages of life, especially after the age of 60 .

When the type of household is taken into account, it becomes obvious that single-parent and one-member households are especially vulnerable to poverty. In most single-parent families, it is women who head the households. According to SORS data form 2015, a quarter of all families are single parent families. 20.3 percent of single-parent households were headed by single mothers, and 4.7 by single fathers (SORS, 2015). The

Table 1

At-risk-of-poverty rate, by gender and age

\begin{tabular}{|c|c|c|c|c|c|c|c|c|c|c|}
\hline & & 2009 & 2010 & 2011 & 2012 & 2013 & 2014 & 2015 & 2016 & 2017 \\
\hline \multirow[t]{3}{*}{ Total } & & 11.3 & 12.7 & 13.6 & 13.5 & 14.5 & 14.5 & 14.3 & 13.9 & 13.3 \\
\hline & Men & 9.8 & 11.3 & 12.2 & 12.5 & 13.5 & 13.7 & 13 & 12.5 & 12.0 \\
\hline & Women & 12.8 & 14.1 & 15 & 14.6 & 15.4 & 15.2 & 15.6 & 15.2 & 14.5 \\
\hline \multirow[t]{3}{*}{ Age 18-64 } & Total & 9.2 & 11 & 11.7 & 12.2 & 13 & 13.7 & 13.6 & 13.4 & 12.6 \\
\hline & Men & 9.1 & 11 & 11.9 & 12.3 & 13.3 & 13.8 & 13.2 & 13.2 & 12.1 \\
\hline & Women & 9.4 & 10.9 & 11.4 & 12 & 12.7 & 13.6 & 14.0 & 13.7 & 13.0 \\
\hline \multirow[t]{3}{*}{ Age 60+ } & Total & 18.2 & 18.8 & 19.1 & 17.3 & 17.8 & 15.9 & 16.3 & 17.4 & 16.1 \\
\hline & Men & 11.7 & 11.1 & 12.3 & 11.4 & 12.1 & 11.4 & 11.5 & 13.0 & 11.8 \\
\hline & Women & 22.7 & 24.3 & 24.1 & 21.8 & 22.1 & 19.3 & 20 & 20.8 & 19.5 \\
\hline
\end{tabular}

Source: SORS, SILC. 
high at-risk-of-poverty rate seen in Table 2 indicates that poverty of women and their dependent children increases when they divorce or separate from their partners. Accordingly, in 2017 the general at-risk-of-poverty-rate decreased, but among single-parent households the risk of poverty increased. The highest at-risk-of-poverty rate though is observed for one-member households, that is, persons who live alone. It is especially high among women in the older age group, with slightly less than half of them being at risk of poverty.

Eurostat data for 2016 (Table 3) show that at-risk-of-poverty rate in the age group 65 and over in Slovenia is higher than the EU27 average. In 17 EU countries, the atrisk-of-poverty rate among older people is lower than in Slovenia; in 19 EU countries, the at-risk-of-poverty rate among older women is lower than in Slovenia, and in 11 countries the rate for men is lower. In the age group 75 and over, the gender gap further widens and the comparison with other EU countries once again reveals how unsatisfactory the situation in Slovenia is - while the at-risk-of-poverty rate among men in this age group in Slovenia is lower than the EU average, the rate among women is much higher than the average. In 18 EU countries, the at-risk-of-poverty rate in this age group irrespective of gender is lower than in Slovenia, in 19 countries poverty among women is lower, and in seven countries poverty among men is lower.

Table 2

At-risk-of-poverty-rate by household type and sex

\begin{tabular}{lcccccccccc}
\hline Type of household & & 2009 & 2010 & 2011 & 2012 & 2013 & 2014 & 2015 & 2016 & 2017 \\
\hline $\begin{array}{l}\text { Single-parent with } \\
\text { dependent children }\end{array}$ & Total & 28.1 & 31.4 & 30.8 & 25.8 & 30.1 & 27.4 & 32.5 & 25.2 & 30.0 \\
& Men & 32.5 & 17.3 & 26.3 & 33.3 & 33.2 & 28.0 & 25.3 & 25.9 & 28.8 \\
One-member 65+ & Women & 54.0 & 49.8 & 49.3 & 44.0 & 42.1 & 38.6 & 41.3 & 41.0 & 39.2 \\
\hline
\end{tabular}

Source: SORS.

Table 3

At-risk-of-poverty rate by gender

\begin{tabular}{|c|c|c|c|c|c|c|c|c|c|c|}
\hline & & 2008 & 2009 & 2010 & 2011 & 2012 & 2013 & 2014 & 2015 & 2016 \\
\hline \multirow{3}{*}{ EU27 65+ } & Altogether & 18.9 & 17.9 & 15.9 & 15.8 & 14.4 & 13.7 & 13.7 & 14.0 & 14.5 \\
\hline & Men & 15.6 & 14.9 & 12.9 & 13.0 & 12.2 & 11.3 & 11.2 & 11.6 & 11.9 \\
\hline & Women & 21.4 & 20.2 & 18.2 & 18.0 & 16.1 & 15.5 & 15.7 & 15.8 & 16.5 \\
\hline \multirow{3}{*}{$\begin{array}{l}\text { Slovenia } \\
65+\end{array}$} & Altogether & 21.3 & 20 & 20.2 & 20.9 & 19.6 & 20.5 & 17.1 & 17.2 & 17.6 \\
\hline & Men & 11.7 & 11.4 & 9.5 & 10.5 & 11.7 & 13.2 & 10.8 & 10.2 & 10.8 \\
\hline & Women & 27.5 & 25.5 & 27.1 & 27.8 & 25 & 25.5 & 21.6 & 22.2 & 22.5 \\
\hline \multirow{3}{*}{$\begin{array}{l}\text { EU } 27 \\
75+\end{array}$} & Altogether & 21.4 & 20.4 & 18.1 & 17.9 & 15.7 & 14.8 & 15.1 & 15.4 & 16 \\
\hline & Men & 17.1 & 16.8 & 14.5 & 14.4 & 12.8 & 11.9 & 11.7 & 12.1 & 12.4 \\
\hline & Women & 24.2 & 22.8 & 20.5 & 20.3 & 17.9 & 16.9 & 17.6 & 17.8 & 18.5 \\
\hline \multirow{3}{*}{$\begin{array}{l}\text { Slovenia } \\
75+\end{array}$} & Altogether & 25.9 & 25.2 & 26 & 27 & 24.5 & 26 & 21.1 & 21.1 & 20.5 \\
\hline & Men & 12.4 & 12.1 & 10.7 & 12 & 12 & 12.6 & 9.7 & 10.2 & 10.1 \\
\hline & Women & 32.2 & 31.4 & 34 & 34.6 & 31.5 & 33.5 & 27.4 & 27.5 & 26.6 \\
\hline
\end{tabular}

Source: EUROSTAT. 


\section{GENDER GAP IN PENSION}

We will now present data on the GGP (Table 4), which is a result of the entire life course until retirement, but also of the eligibility criteria for retirement and distribution of pensions (Hrženjak, 2015). In the retirees group the at-risk-of-poverty level increased in 2016, although the general atrisk-of-poverty level decreased in the same year (see Table 1).

Table 4

At-risk-of-poverty rate among retired people by gender, Slovenia, on the yearly basis

20092010201120122013201420152016

\begin{tabular}{lllllllll}
\hline Total & 17.4 & 18.3 & 18.4 & 17.0 & 17.5 & 15 & 15.9 & 16.9
\end{tabular}

\begin{tabular}{lllllllll}
\hline Men & 12.2 & 12.1 & 12.6 & 12 & 12.8 & 11 & 11.4 & 12.6 \\
\hline
\end{tabular}

Women $20.722 .522 .3 \quad 20.420 .7 \quad 17.9 \quad 19.220 .1$

Source: SORS (SILC). Source for 2015, 2016 EUROSTAT (SILC).

In Slovenia, the GGP in 2012 amounted to 24 percent (Burkevica et al., 2015). In the same year the lowest percentage in the EU was recorded in Latvia - only 4 percent - with that in Estonia and Slovakia being slightly higher. In most East European countries, it was lower than 16 percent. The biggest GGP was recorded in Germany -45 percent (and a similar situation is seen in Luxembourg, The Netherlands, and Great Britain) (Burkevica et al., 2015: 20). The gap is also high in Nordic countries, for example in Sweden (30 percent) and Finland (27 percent), although those countries pay significant attention to gender equality and are considered welfare states. It is also worth noting that in Slovenia the GGP within households is higher than in most other EU countries, except France, Germany and Belgium (Tinios et al.., 2015.: 53).

Table 5 contains data on pension supplement in Slovenia. The supplement was allocated to persons whose pensions were too low and it was means-tested (calculated based on the wealth and household income). Before the implementation of the Social Assistance Benefits Act in 2012 (Ur. 1. RS, 61/10., 40/11., 14/13., 99/13. in 90/15.), there were 46,749 recipients of the pension supplement in Slovenia (ZPIZ, Annual Report 2011). Since data are not disaggregated by sex we can only presume that most survivor and widow pensions were received by women, given that recipients belong in the generation in which mostly women were responsible for care work in the families.

The new law regulating the social security that was introduced in 2012 changed the definition of the pension supplement which is now defined as a social cash allowance for which retired persons had to apply at social services. Due to changed eligibility criteria, the number of recipients drastically decreased (from 46,749 in 2011 to 9,298 in 2014). The eligibility criteria included income and property that is claimed by the state after recipient's death. In order to ensure the right to the inheritance the state has a right to put a note in the land register. After the legislation was amended in 2016, the number of recipients again began to rise and the change will probably have a positive effect on the risk of poverty among older women, but results will be visible only in a few years.

Table 5

Pension supplement as a social assistance benefit in cash

\begin{tabular}{lccc}
\hline Date & Applicants & Amount & $\begin{array}{c}\text { Average } \\
\text { value }\end{array}$ \\
\hline 01.05 .2014 & 9,298 & $1,368,852$ & 147.22 \\
\hline 01.05 .2015 & 10,059 & $1,555,385$ & 154.63 \\
\hline 01.05 .2016 & 10,566 & $1,637,008$ & 154.93 \\
\hline 01.05 .2017 & 15,277 & $2,328,871$ & 152.44 \\
\hline
\end{tabular}

Source: MDDSZ.

Women who were not employed and do not qualify for any type of pension (old age 
pension incl. early retirement pension or partial pension, disability pension, survivor or widow pension), receive social assistance in cash and depend on their close relatives, since they cannot apply for cash allowances before all options within the family are exhausted. Unfortunately, there is no data on the share of women not receiving pension. The Social Assistance Benefits Act stipulates that the family is responsible for securing livelihood, with the state stepping in only when the family is unable to support all family members. Since both income and property is taken into account, it may happen that older women fail to fulfil criteria for social assistance in cash although they do not have any means of livelihood. Data on the poverty risk among older women do not in itself offer sufficient basis for the understanding of the process of poverty accumulation in old age, so to gain a better insight we will also make use of the available data on the life courses of women.

\section{TRAJECTORIES IN WOMEN'S LIFE COURSES WHICH INFLUENCE POVERTY IN OLD AGE}

Slovenia has recently been experiencing the re-traditionalization of women's roles, but the change is not yet reflected in the situation of older women, since women in the age group 75 and over who are currently most vulnerable to poverty lived most of their lives under the socialism. However, the capitalism of today determines their livelihood options (the pension coefficients, as well as income supplements or other financial sources if they do not fulfil eligibility criteria for pension). Therefore, the two questions that need to be answered when considering the issue of poverty in old age are as follows: 1) Do women's specific life courses affect their ability to fulfil pension eligibility criteria and how high will their pensions be? 2) How does the state respond to structural inequalities that accumulate during life course - does it mitigate or aggravate them, or perhaps even cause them? Gender specific practices, institutional frameworks and national policies shape the structural environment in which women live. Their situation in old age is primarily influenced by the education level they attained, their employment and reconciliation of professional and family life, with the latter primarily depending on the distribution of caring responsibilities in private life. What is important is how these trajectories in women's life courses intersect. We are not in a position to conduct an in-depth analysis of this issue due to the scarcity of data on the distribution of care work, but the existing data is nevertheless sufficient to obtain an understanding of the problem.

Poje and Vidic (2015) write that according to Eurostat data for 2013, gender pay gap (GPG) in Slovenia is 3.2 percent, but a more detailed survey of data reveals substantial differences among various fields of work. Penner et al. (2012) studied GPG in Slovenia and established that is was quite high. During the period 2003-2007, men earned on average 23 percent more than women; the GPG within companies between men and women who performed the same work was 18 percent. Poje and Vidic (2015: 6) concluded that differences in men's and women's gross salaries existed on various levels - the field of work, profession and job positions. In 2014, women's salaries in financial and insurance companies were 25.3 percent lower than those of men; in healthcare and social security institutions, the gap was 25 percent. The biggest differences were observed in the group of experts, where women experts' salaries stood at 85.2 percent of men's salaries, or nominally they were EUR 365 lower. The labour market is therefore not gender neutral, but rather develops gender specific work culture, norms, values, rules, promotion and reward 
systems, as well as various other incentives and working time regimes which are ignorant to the needs of privacy and intimate life (Hrženjak, 2015: 8).

An important factor in women's life courses is education. In 2016, according to SORS data, 12,557 men compared to 18,410 women completed tertiary education. More women completed doctoral studies (274 women compared to 263 men according to the Bologna process, and 219 women compared to 156 men according to the previous programme); master's degree was received by 4,909 women compared to 2,713 men. Furthermore, 3,782 women completed their tertiary education before the age of 24, compared to 2,338 men. Women in Slovenia are better educated than men, but the GPG in 2014 in the tertiary education group was 17.3 percent; in the elementary education group the gap amounted to 15.6 percent. The smallest gap is recorded in the group with the secondary level of education - 12 percent (Poje and Vidic, 2015: 5). Research studies conducted by the Slovene Peace Institute showed that highly educated women partners of men with leading jobs who spend up to 12 hours per day at work, opt for parttime employment once they have a child. They also often accept jobs for which they are overqualified (Hrženjak, 2015: 8). The survey on the active and non-active population conducted by SORS and based on 7,000 sample households, showed that in 2015,23 women chose to act as a supporting family member, ${ }^{3}$ compared to 14 men only.

SORS data further reveal that despite the fact that more women than men in Slovenia attain higher education levels the employment rate among women in 2016 was 45 percent. More women than men, i.e. 62 percent, work in the public sector. But in public companies, men constitute 58 percent of the workforce. Needless to say, salaries in public companies are higher than in the overall public sector. Women make 39 percent of the workforce in the private sector. More women than men work as carers, or provide care for family members. In 2016, women were predominant (constituting more than three fourths of the workforce) in the fields of healthcare, education, administration, cleaning and food preparation, and in all cases they earned less than men on average.

In the healthcare and social care and welfare fields, the gross salary for men in 2016 was EUR 2,267, compared to EUR 1,732 for women (SORS, Structure of salaries 2016). SORS data for 2013 show that 85 percent of employees in social care institutions were women $(5,174$ out of 6,072 altogether). The total capacity of the residential homes is 14,292 beds (Mali, 2010).

Most care workers in in-home based care services are women, and their earnings average around the minimum wage. On December 31, 2015, there were 1,024 women care workers in in-home based care services, who cared for 7,100 users of service (IRSSV, 2016). It is more difficult for women to harmonize employment and care work in their families, since they accomplish much more housework than men. Sori (2017) cites data from the Slovenian Public Opinion Survey 2012, in which men stated that they spent 10.06 hours per week on housework, compared to 22.69 hours spent by women. Slightly more than 12 percent of men do not perform any housework, with only 1.2 percent of women stating the same.

\footnotetext{
${ }^{3}$ Supporting family members are persons who are formally not employed or self-employed but in the week before the survey they worked on a family farm, in a family workshop, a family company or were involved in some other kind of family activity that generates income although they do not receive salary for their work
} 


\section{CONCLUSION}

Gender inequalities in old age reflect previous life course patterns. They are influenced by many interacting processes and causes, and cannot be explained unless we take into account the characteristics of life courses (Schaffner Goldberg, 2010). Life courses are affected by cultural and social specificities, which can shed a light on the understanding and interpretation of structural changes such as de-standardization and de-regulation of life courses and transitions (Heinz, 1997; Leccardi, 2005) or individualization of social requirements and responsibilities (Walther, 2006; Ule, 2006; Layte and Whelan, 2002).

Data on the poverty among older women in Slovenia suggest the scope of the problem, but its interpretation is not straightforward and cannot be based on quantitative data only. The conclusions we can draw from available data at the moment are:

- Although the at-risk-of-poverty rate has been decreasing lately, during the period of economic crisis the poverty rate in Slovenia increased more than in most other EU countries and Slovenia is still lagging behind.

- Despite the slight decrease of the at-riskof-poverty rate in general, for certain social groups - namely single-parent families and older women aged $65+$ and $75+$ - the rate increased or remained the same.

- While the at-risk-of-poverty rate for men in Slovenia is lower than the EU27 average, the rate for women is higher than the EU average. The gap is therefore gender specific.

- The survey of data covering longer time periods shows oscillations and a slight rise in the risk-of-poverty rate in the age group 65+, which can be attributed to the drastic decrease in the number of persons - most of them women - who are eligible to receive pension supplement.
- The gender gap in terms of the at-risk-ofpoverty rate among pensioners is quite high. Gender gap in pension in Slovenia is much higher than in other East European countries.

- Although more women in Slovenia attain higher education levels than men, their earnings are lower, not only in the private sector but also in the public sector where salaries are strictly regulated.

- Women still perform two times as much housework and family care work as men.

Put differently, employed women are paid less than men, they have less convenient employment options, and it is more difficult for them to harmonize work and family life. All of this constitutes a specific pattern that affects their economic situation in old age. Women are subject to the mechanisms of the labour market, education system and social institutions which in many ways affect their prospects (Rener, 2010). The accumulation of inequalities in old age can therefore be interpreted as a consequence of women's lower participation in the labour market, lower per-hour rate for their work, and a lower number of working hours and consequently years (Bettio et al., 2013). At the same time, we should not overlook the importance of the distribution of unpaid housework (Umberson et al., 2014). Undoubtedly, the GPG is also a consequence of maternity leaves, interruptions of employment because of childcare or care for the disabled, sick or old relatives, or frequent sick leaves taken to provide care for children, but these are not the only reasons. Horizontal and vertical gender segregation on the labour market, consecutive paternal leaves, scarce options for the harmonization of paid work and care responsibilities and other obstacles related to the re-entering of the labour market after childbirth, have negative effect on the height of pension and cause gender inequalities in old age (Vosko et 
al., 2009.; Maestripieri, 2015). Penner et al. (2012) write that gender as analytical category is important when studying the economic processes, because it is necessary to understand the interaction of the private and public sphere. Life-long care for children or older relatives and similar tasks affect retirement options for women, which in turn determines the height of their pensions; they are thus exposed to a high risk of poverty and economic dependence (Ginn, 2003; Heap and Fors, 2015; Mali, 2014).

The welfare-state should support the reconciliation of work and care responsibilities through a number of services and gender equality policies, but poverty among older women shows that such measures fall short of expectations. Daly (2000) states that a welfare-state has an important role in the shaping of social (in)equality; it may mitigate or aggravate it, depending on how it regulates or determines relations among the state, the market and the family. Although specific measures may contribute to gender equality, they may also cause gender inequalities, which accumulate in old age (de Graaf and Maier, 2015; Seabrook and Avison, 2012; Komp and Johansson, 2015).

\section{LITERATURE}

Barrientos, A., Gorman, M., \& Heslop, A. (2003). Old age poverty in developing countries: Contributions and dependence in later life. World Development, 31(3), 555-570. https://doi.org/10.1016/ S0305-750X(02)00211-5

Baxter, J., Hewitt, B., \& Haynes, M. (2008). Life Course Transitions and Housework: Marriage, Parenthood, and Time on Housework. Journal of marriage and family, 70(2), 259-272. https://doi. org/10.1111/j.1741-3737.2008.00479.x

Bettio, F., Tinios, P., \& Betti, G. (2013). Gender gap in pensions in the EU. Luxemburg: European Union.

Börcsh Supan, A., Brandt, M., Hank, K., \& Schroeder, M. (Eds.). (2011). The individual and the welfare state. Life histories in Europe. Berlin: Springer.
Burkevica, I., Humbert, A. L., Oetke, N., \& Paats, M. (2015). Gender gap in pensions in the EU. Vilnius: EIGE.

Daly, M. (2000). The gender division of welfare. Cambridge: Cambridge University Press.

Dewilde, C., Van Den Bosch. K., \& Van Den Heede, A. (2011). Separation: Consequences for wealth in later life. In A. Borsch-Supan, M. Brandt, K. Hank \& M. Schroder (Eds.), The Individual and the Welfare State. Life Histories in Europe (pp. 103-114). Heidelberg: Springer.

Dragoš, S., \& Leskošek, V. (2016). Gospodarstvo za $1 \%$ (The Economy for 1\%). Oxfam's report No. 210. Accompanying study. Ljubljana: Založba cf*.

European Institute for Gender Equality. (2015). Gender Equality Index: Slovenia. Available at http:// eige.europa.eu/gender-equality-index/2015/SI

Gianni, B., Bettio, F., Georgiadis, T., \& Tinios, P. (2015). Unequal ageing in Europe: Women's independence and pensions. New York: Palgrave Macmillan.

Ginn, J. (2003). Gender, pensions and the lifecourse: How pensions need to adapt to changing family forms. Bristol: Policy Press.

Gornick, C. J., Sierminska, E., Munzi, T. \& Smeeding, M. T. (2009). Income, assets and poverty: Older women in comparative perspective. Journal of Women, Politics \& Policy, 30(2-3), 272300. https://doi.org/10.1080/15544770902901791

Gornick, C. J., Sierminska, E. \& Smeeding, M. T. (2009). The income and wealth packages of older women in cross-national perspective. The Journals of Gerontology: Series B, 64(3), 402-414. https://doi.org/10.1093/geronb/gbn045

Goedemé, T. (2012). Recent trend in minimum income schemes for Europe's elderly. Gini Discussion Paper 27. Amsterdam: AIAS. Available at http://www.gini-research.org/system/ uploads/370/original/ DP_27_-_Goedem_. pdf?1342003880

de Graaf, W., \& Maier, R. (2015). The welfare state and the life course: Examining the interrelationship between welfare arrangements and inequality dynamics. Social policy \& administration, 5l(1), 40-55. https://doi.org/10.1111/spol.12153

Heap, J., \& Fors, S. (2015). Duration and accumulation of disadvantages in old age. Social indicators research, 123(2), 411-429. https://doi. org/10.1007/s11205-014-0744-1

Heinz, W. R. (Ed.). (1997). Theoretical advances in life course research. Weinheim: Deutscher Studien Verlag. 
Hrženjak, M. (2015). Pokojninski razkorak z vidika (ne)enakosti spolov. Delavska enotnost, 74(33), 8-10.

The Social Protection Institute of the Republic of Slovenia. (2015). Spremljanje izvajanja programov socialnega varstva: Poročilo o izvajanju programov v letu 2014 (Monitoring the implementation of the social protection programmes). Final report. Ljubljana: The Social Protection Institute of the Republic of Slovenia.

Kanjuo-Mrčela, A., \& Černigoj-Sadar, N. (2011). Social policies related to parenthood and capabilities of Slovenian parents. Social politics, 18(2), 199-231. https://doi.org/10.1093/sp/jxr010

Komp, K., \& Johansson, S. (Eds.). (2015). Рориlation ageing from a lifecourse perspective: Critical and international approaches. Bristol: Policy Press.

Layte, R., \& Whelan, T. C. (2002). Cumulative disadvantage or individualisation? A comparative analysis of poverty risk and incidence. European Societies, 4(2), 209-233. https://doi. org/10.1080/14616690220142790

Leccardi, C. (2005): Facing uncertainty: Temporality and biographies in the new century. Young, 13(2), 123-146. https://doi. org/10.1177/1103308805051317

Leskošek, V., Smolej Jež, S., Rihter, L., Boškić, R., Kresal, B., \& Breznik, M. (2013). Revščina zaposlenih (Working poor). Ljubljana: Sophia.

Leskošek, V. (2016). Care between love and money. Teorija in praksa, 53(6), 1356-1368.

Lyberaki, A., Tinios, P., \& Papadoudis, G. (2011). Atypical work patterns of women in Europe: What can we learn from SHARELIFE? In A. Börcsh Supan, M. Brandt, K. Hank \& M. Schroeder (Eds.), The Individual and the Welfare State. Life Histories in Europe (pp. 37-150). Heidelberg: Springer.

Lewis, J. (2009). Work-family balance, gender and policy. Cheltenham: Edward Elgar.

Maestripieri, L. (2015). Gendering social vulnerability. The role of labour market de-standardisation and local welfare. In D. Kutsar \& M. Kuronen (Eds.), Local Welfare Policy Making in European Cities (pp. 51-67). Heidelberg: Springer.

Mali, J. (2010). Social work in the development of institutional care for older people in Slovenia. European Journal of Social Work, 13(4), 545559. https://doi.org/10.1080/13691450903403784

Mali, J. (2014). The role of social work in the epoch of intergenerational solidarity in society. Revija za socijalnu politiku, 21(2), 111-131. https://doi. org/10.3935/rsp.v21i2.1188

Novak, M. (1992). Revščina v 80. letih v Sloveniji (Poverty in the 1980s in Slovenia). Teorija in praksa, 29(7-8), 651-661.

Organisation for Economic Co-operation and Development. (2018). Social spending. Available at https://data.oecd.org/socialexp/social-spending. htm\#indicator-chart

Penner, M. A., Kanjuo Mrčela, A., Bandelj, N., \& Petersen, T. (2012). Neenakost po spolu v Sloveniji od 1993 do 2007: Razlike v plačah v perspektivi ekonomske sociologije (Gender inequalities in Slovenia 1993-2007: the gender pay gap viewed from the perspective of the economic social studies). Teorija in praksa, 49(6), 854-877.

Poje, A., \& Vidic, I. (2015). Razlike v plačah po spolu: mit ali resnica? (Gender pay gap: a myth or a reality?). Delavska enotnost, 74(33), 5-6.

Rener, T. (2010). Youth: The trap of individualisation in a global era. Annales. Series historia et sociologia, 20(1), 71-80. http://www.dlib.si/details/ URN:NBN:SI:DOC-KIGVNZFO

Schaffner Goldberg, G. (Ed.). (2010). Poor women in rich countries: The feminisation of poverty over the life course. Oxford: Oxford University Press.

Seabrook, A. J., \& Avison, R. W. (2012). Socioeconomic status and cumulative disadvantage processes across the life course: Implications for health outcomes. Canadian Review of Sociology, 49(1), 50-68. https://doi.org/10.1111/j.1755618X.2011.01280.x

Stanovnik, T. (1992). Perception of poverty and income satisfaction. Journal of Economic Psychology, 13(1), 57-69. https://doi.org/10.1016/01674870(92)90052-9

The Statistical Office of the Republic of Slovenia. (2015). Households and Families, 2015. Available at http://www.stat.si/StatWeb/News/ Index/5465

The Statistical Office of the Republic of Slovenia. (2016a). Strukturna statistika plač (The structural statistics of salaries), 2016. Available at http://www.stat.si/StatWeb/News/Index/6987

The Statistical Office of the Republic of Slovenia. (2016b). Kazalniki dohodka in revščine: Metodološka pojasnila (Indicators of income and poverty: explanation of methodology), 2016. Available at http://www.stat.si/StatWeb/File/ DocSysFile/8141

The Statistical Office of the Republic of Slovenia. (2018). Mednarodni dan žensk 2018 (The International Women's Day 2018). Available at http:// www.stat.si/StatWeb/News/Index/7279 
Šori, I. (2017). Statistični podatki o vključenosti moških v skrbstveno delo v zasebni sferi v Sloveniji (Statistical data on the inclusion of men into care work in the private sphere in Slovenia). Poročilo v okviru projektna Moškosti, enakost, skrbstvene prakse - MESP (The report for the project Masculinity, Equality, Carework Practices). Ljubljana: Peace Institute. Available at http://www.mirovni-institut.si/wp-content/uploads/2017/10/Skrbstveno-delo-v-zasebni-sferi. pdf

Tinios, P., Bettio, F., Betti, G., \& Georgiadis, T. (2015). Men, women and pensions. Brussels: European Commission, Directorate-General for Justice.

Ule, M. (2006). Identiteta in oblastni identifikacijski mehanizmi (Identity and governmental identification mechanisms). Revija 2000, 37(186-188), 122-132.

Ule, M. (2014). Spremembe vsakdanjega življenja in življenjskih potekov v sodobnih globaliziranih družbah (Changes in everyday life and life courses in contemporary globalized societies). Teorija in praksa (special issue), 51, 309-327. http://dk.fdv.uni-lj.si/db/pdfs/TiP2014_P_Ule.pdf
Umberson, D., Williams, K., Thomas, A. P., Liu, H., \& Thomeer, M. B. (2014). Race, gender, and chains of disadvantage: Childhood adversity, social relationships, and health. Journal of Health and Social Behavior, 55(1), 20-38. https://doi. org/10.1177/0022146514521426

Vosko, L., Macdonald, M., \& Campbell, I. (Eds.). (2009). Gender and the contours of precarious employment. London: Routledge.

Zakon o socialnovarstvenih prejemkih (The Social Assistance Benefits Act). Uradni list RS, št. 61/2010, 40/2011, 14/2013, 99/2013, 90/2015.

Pension and Disability Insurance Institute of Slovenia. (2011). Letno poročilo 2011 (Annual report 2011). Available at https://www.zpiz.si/cms/content/letnoporocilo2011

Walther, A. (2006). Regimes of youth transitions: Choice, flexibility and security in young people's experiences across different European contexts. Young, 14(2), 119-139. https://doi. org/10.1177/1103308806062737 


\title{
Sažetak \\ SIROMAŠTVO STARIJIH ŽENA U SLOVENIJI
}

\author{
Vesna Leskošek \\ Fakultet za socijalni rad, Sveučilište u Ljubljani \\ Ljubljana, Slovenija
}

Rad nastoji problematizirati socijalno relevantno, ali politički zanemareno pitanje siromaštva među starijim ženama. Podatci pokazuju da je siromaštvo među ženama izazov za većinu zemalja članica Europske unije i izvan nje. Ipak, ono se ne može objasniti bez. razumijevanja rodno specifičnog tijeka života žena. Razlike između starijih žena $i$ muškaraca predočujemo prema riziku od siromaštva i uspoređujemo ih s onima u zemljama članicama EU-a. Rad se temelji na sekundarnim podatcima, tj. na Istraživanju dohotka $i$ životnih uvjeta (EU SILC) koji omogućuju usporedbe između zemalja članica EU-a. Ustanovili smo da se rodna razlika u riziku od siromaštva povećava u starijoj dobi. Stopa rizika od siromaštva za žene mnogo je veća u Sloveniji nego u drugim zemljama članicama EUa. Razlika je posebno velika u dobnoj skupini žena starijih od 75 godina. Slovenija nije bila uspješna u rješavanju problema rizika od siromaštva jer nije uvela posebne mjere za smanjivanje općeg rizika od siromaštva i smanjivanje rodne razlike.

Ključne riječi: siromaštvo, tijek života, rodno uvjetovana razlika u mirovinama, zaposlenost, pružanje njege. 